\title{
Effect of Job Promotion on The Performance of Civil Servants AT The Regional Office of The Ministry of Religion of Banten Province Mediated By Job Satisfaction
}

\author{
Encep Saefullah \\ Faculty of Economics and Business, Bina Bangsa University \\ *Corresponding Author: \\ Email: encepsaefullah82@gmail.com
}

\begin{abstract}
.
The objectives of this research was aims to determine the direct effect of job promotion on employee performance and job satisfaction, the direct effect of job satisfaction on employee performance and the effect of job promotion on employee performance through job satisfaction as an intervening variable.

Data collection was carried out by distributing questionnaires. This study used quantitative data analysis with SPSS version 23. The total population was 205 ASN employees in the Regional Office of the Ministry of Religion, Banten Province. Samples were collected using random sampling technique, which obtained 67 respondents.

The results of this study indicated that Job Promotion had a direct influence on employee performance, Job Promotion had no direct effect on job satisfaction, Job Satisfaction had no direct effect on employee performance and the indirect effect of Job Promotion on Employee Performance through Job Satisfaction showed a smaller percentage compared with the percentage of direct effect.
\end{abstract}

Keywords: Job Promotion, Employee Performance, Job Satisfaction

\section{INTRODUCTION}

Human resources are a very important factor, especially for government or private organizations. Every public and private organization is required to work more quickly, effectively and efficiently. Therefore, employees discipline in agency activities needs to be accompaned with abilities in terms of knowledge and skills. For this reason, the management of human resource needs to be given top priority so that the utilization by the said organization or agency is in line with the expectation in an effort to achieve predetermined goals.

Managing human resources in an organization or agency is not an easy job, because humans are different resources from other production factors. Humans have heterogeneous feelings, thoughts, desires and backgrounds. Humans cannot be controlled and ordered like machines, capital or buildings, so that managing human resources is a difficult and complex problem. Humans in an organization will try to obtain the desired position by maximizing their expertise, skills, abilities and energy at work in the hope of increasing their welfare to be better than before. Human resource planning is the process of anticipating and making provisions/requirements to regulate the flow of labor movements inward (new jobs), inside (promotion, moving, and demotion), and outward (retirement, layoff and dismissal) within the organization. Human resource planning is also certain steps taken by management to ensure that the organization provides the right manpower to occupy various right positions, functions and job at the right time [3].

One indicator of a good performance for an organization or agency is determined by the performance of its employees. Performance is the result of a process that is referenced and measured over a certain period of time based on predetermined terms or agreements. Employees are promoted 
based on the value of each performance-based assessment. For that leadership plays an important role in deciding which employees are entitled to be promoted [1].

Employee performance is based on satisfaction at work. Job satisfaction will be achieved if there is a conformity between an employee's expectations and the existing reality he finds within the work place. Job satisfaction is the employee's feelings about his job, whether happy/like or not happy/dislike as a result of employee interaction with the work environment or as a perception of mental attitudes, as well as a result of the employee's assessment towards his job.

Job satisfaction is closely related to employee performance. It is obtained one of which is from job promotion. According to Levi [6], one aspect of job satisfaction is promotion. Employees who feel satisfied at work and get a promotion will show optimal performance in their work. The result of a study conducted [9] entitled the effect of job promotion, compensation, and job stress on the performance of employees of PT. Tema (Trijaya Exel Madura) through job satisfaction as an intervening variable showed that promotion had a significant effect on performance. Promotion plays an important role for every employee, even becomes the dream that is always dreamed for.

\section{Performance}

The term performance is derived from the words Job Performance/Actual Performance (which has been achieved by someone). According to Mangkunegara in the Encep Saefullah Journal [13], performance (work performance) is the result of work in quality and quantity which is achieved by an employee in carrying out his duties according to the responsibilities given to him. Meanwhile, according to Mangkunegara [7] the factors that influence performance achievement are: 1) the ability factor; and 2) the motivation factor. According to Moeheriono [10] there are six measures of performance indicators, but each organization can develop it according to the Mission developed. The six categories include: Effective, Efficient, Quality, Timeliness, and Productivity.

\section{Job Promotion}

According to Irham Fahmi [2] promotion is an increase in the position of an employee from a previous position to a higher position. In order to carry out a promotion, a company or agency must determine conditions in advance so as guarantee that the employee who will be promoted will have the ability to hold a higher position. According to Hasibuan [4], there are 4 types of job promotions, namely (1) Temporary promotions, (2) Permanent promotions, (3) Small promotions and (4) Dry promotions. According to Hasibuan [5], job promotion indicators include: Honesty, Discipline, Job Performance, Cooperation, Skills, Loyalty and Leadership.

\section{Job satisfaction}

Job satisfaction reflects a person's feelings about his job. This can be seen in the positive attitude of employees towards work and everything they face within their work environment. According to Edy Sutrisno [15] Job Satisfaction is a problem that is quite interesting and important, because it has proven to be of great benefit to the interests of individuals, organizations or industries. According to Robbins [12] the indicators that determine job satisfaction are: 1) Mentally challenging work 2) Supporting working conditions 3) Appropriate salary or wages 4) Compatibility between Personality and work 5) Supportive co-workers.

\section{METHODS}

This research refers to research previously conducted by Wahyu Maulana [8] "Effect of Leadership, Compensation and Job promotion at PT Bank Jatim, Tbk Pamekasan Branch Mediated by Job Satisfaction". This study used a survey method with a correlational quantitative approach. Correlational study is intended to determine the effect between two or more variables without any attempt to influence these variables so that there is no variable manipulation.

The current study was conducted at the Regional Office of the Ministry of Religion of Banten Province. The populations in this study were 205 employees of the Civil Servants (ASN), and the samples in this study were 67 ASN employees selected with random sampling technique. The study 
data collection techniques included interviews, observation, and questionnaires. This study involved primary and secondary data. The data analysis techniques used here were multiple linear regression analysis and path analysis using SPSS version 23.

\section{RESULTS AND DISCUSSION \\ Results of Validity and Reliability Tests}

Validity test was carried out based on item analysis and it was stated that all items were valid with the criteria of $r_{\text {count }}<r_{\text {table. }}$. Furthermroe, the reliability test results showed that the data were reliable according to the criteria for the values of Cronbach alpha of $0.930,0.910,0.917$ for promotion, job satisfaction and employee performance, respectively. Because all Cronbach alpha values were higher than 0.6 , it can be concluded that all variables were reliable.

Multiple Linear Regression Analysis Results

Table 1. Multiple Linear Regression Analysis

\begin{tabular}{|c|c|c|c|c|c|c|}
\hline & standardize & ed Coefficie & $\begin{array}{l}\text { tandardized } \\
\text { Coefficients }\end{array}$ & & & \\
\hline Model & B & Std. Error & Beta & $\mathrm{T}$ & Sig. & \\
\hline (Constant) & 22.905 & 5.793 & & 3.954 & & .000 \\
\hline Promotion & .373 & .098 & .430 & 3.800 & & .000 \\
\hline satisfaction & .124 & .110 & .127 & 1.128 & & .264 \\
\hline
\end{tabular}

a. Dependent Variable: Employee Performance

A constant of 22,905 indciated that if the Job Promotion and Job Satisfaction were zero, then the Employee Performance was 22.905.

Multiple Correlation Coefficient Analysis Results

Table 2.Multiple Correlation Coefficient Analysis

$\begin{array}{cccccc}\text { Model } & \mathrm{R} & \text { R Square } & \text { Adjusted R Square } & \text {. Error of the Estin } & \text { Durbin-Watson } \\ 1 & .476^{\mathrm{a}} & .226 & .202 & 7.835 & 2.293\end{array}$

a. Predictors: (Constant), Job Satisfaction, Job Promotion

b. Dependent Variable: Employee Performance

Source: Processed SPSS 23 Data (2019)

Based on the table above, the correlation value between Job Promotion and Job Satisfaction on Employee Performance was 0.476, (in the moderate range of 0.40-0.599).

Path Analysis Test Results

Path analysis is the application of regression analysis to estimate the causal relationship between variables (causal models) that have been previously established based on theory.

\section{a. First Regression Equation}

The results of the first regression analysis on the effect of job promotion on job satisfaction can be seen in the table below:

Table 3. Partial Test of Job Promotion on Job Satisfaction Model Summary

$\begin{array}{ccccc}\text { Model } & \mathrm{R} & \mathrm{R} \text { Square } & \text { Adjusted R Square } & \text { Std. Error of the Estimate } \\ & .233^{\mathrm{a}} & .054 & .040 & 8.815\end{array}$

a. Predictors: (Constant), Job Promotion

The table above showed the R2 (R Square) value of 0.054 , then the following calculation was obtained:

The amount of e1 $=\sqrt{ } 1-\mathrm{R} 2=\sqrt{ } 1-0.054=\sqrt{ } 0.946=0.972$ 
Table 4. Regression Analysis of Job Promotion on Job Satisfaction

\section{Coefficients ${ }^{\mathrm{a}}$}

ıstandardized Coefficiendardized Coefficis

$\begin{array}{lrcccc}\text { Model } & \text { B } & \text { Std. Error } & \text { Beta } & \text { T } & \text { Sig. } \\ \text { (Constant) } & 35.768 & 4.776 & & 7.489 & .000 \\ \text { Job Promotion } & .207 & .107 & .233 & 1.930 & .058\end{array}$

a. Dependent Variable: Job Satisfaction

Based on the table above, the beta value was 35.768 and the regression equation was as follows:

$\mathrm{Z}=\alpha+\mathrm{P} 2 \mathrm{X}_{1}+\mathrm{e} 1$

$Z=35.768+0.207+0.972$

The Unstandardized Beta Coefficient of Job Promotion was 0.207 with a significance of 0.058 , which is higher than 0.05 which indicated that there was no direct and significant effect on job satisfaction. the value of the Unstandardized Beta coefficient of 0.207 was the path value of P2.

\section{b. Second Regression Equation}

The results of the second regression analysis on the effect of job promotion on employee performance through job satisfaction can be seen in the table below:

Table 5. Partial Test of Job Promotion on Employee Performance through Job Satisfaction Model Summary

$\begin{array}{ccccr}\text { Model } & \mathrm{R} & \mathrm{R} \text { Square } & \text { Adjusted R Square } & \text { Std. Error of the Estimate } \\ & .476^{\mathrm{a}} & .226 & .202 & 7.835\end{array}$

a. Predictors: (Constant), Job Satisfaction (Z), Job Promotion

The table above showed the R2 (R Square) value of 0.226 , then the following calculation was obtained:

$\mathrm{e} 2=\sqrt{ } 1-\mathrm{R} 2=\sqrt{ } 1-0.226=\sqrt{ } 0.774=0.879$

Table 6 Analysis of Job Promotion Regression on Employee Performance through Job Satisfaction Coefficients $^{\mathrm{a}}$

$$
\begin{array}{cc}
\text { Unstandardized } & \text { Standardized } \\
\text { Coefficients } & \text { Coefficients }
\end{array}
$$

\begin{tabular}{lrrrrr} 
Model & \multicolumn{1}{c}{ B } & Std. Error & Beta & $\mathrm{T}$ & \multicolumn{1}{c}{ Sig. } \\
(Constant) & 22.905 & 5.793 & & 3.954 & .000 \\
Job Promotion & .373 & .098 & .430 & 3.800 & .000 \\
Job Satisfaction $(\mathrm{Z})$ & .124 & .110 & .127 & 1.128 & .264
\end{tabular}

a. Dependent Variable: Employee Performance

Based on the table above, the regression equation was as follows:

$\mathrm{Y}=\alpha+\mathrm{P} 1 \mathrm{X} 1+\mathrm{P} 2 \mathrm{Z}+\mathrm{e} 2$

$\mathrm{Y}=22,905+0.373 \mathrm{X} 1+0.124+0.879$

The equation showed that:

1. The coefficient value of Unstandardized beta for job promotion was 3.73 with a significance of 0.000 , which meant that it was lower than 0.05 . Thus, job promotion had a direct and significant effect on employee performance. The unstandardized beta coefficient value of 0.373 was for the path $\mathrm{P} 1$.

2. coefficient value of Unstandardized beta for job satisfaction was 0.124 with a significance of 0.264 , which meant that it was higher than 0.05 . Thus, job satisfaction had no direct effect on employee performance. The Unstandardized beta coefficient value of 0.124 was for the path P3.

Based on the study results, the path analysis model was determined as follows: 


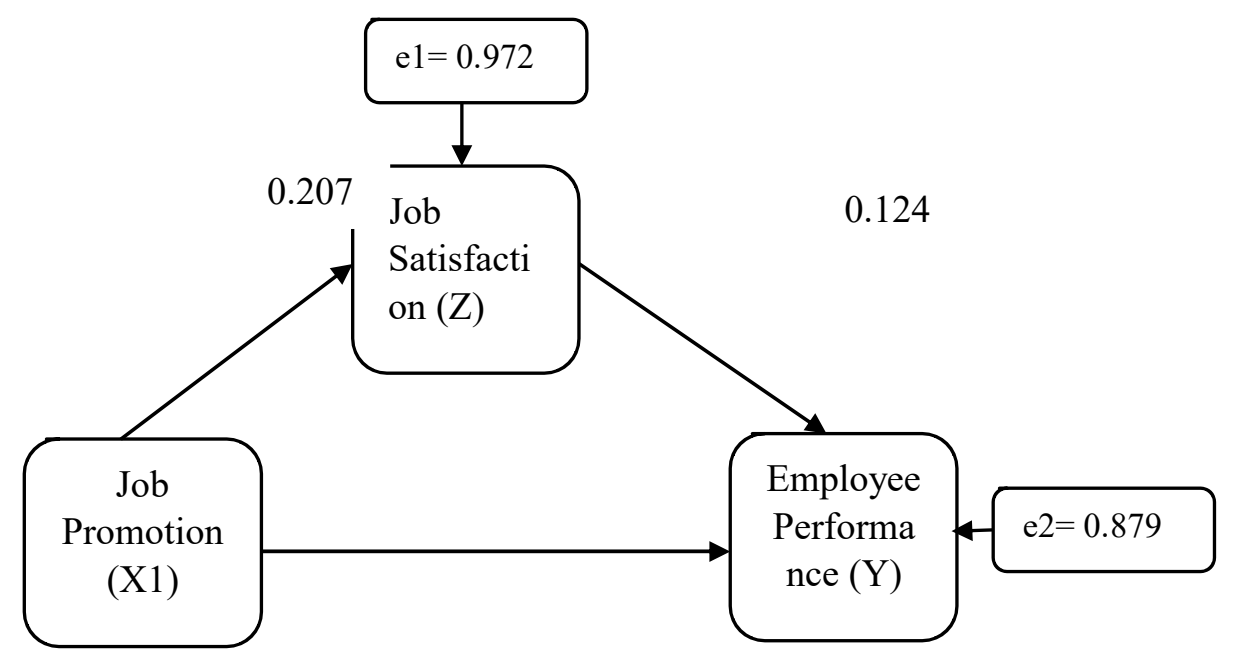

Fig. 1 Path Analysis Result

\section{c. Analysis for Sobel Test with Process 3 in SPSS 23}

To find out both direct and indirect effect of job promotion variable on employee performance through job satisfaction, a single test with Process 3 was performed in SPSS 23. The results are as follows:

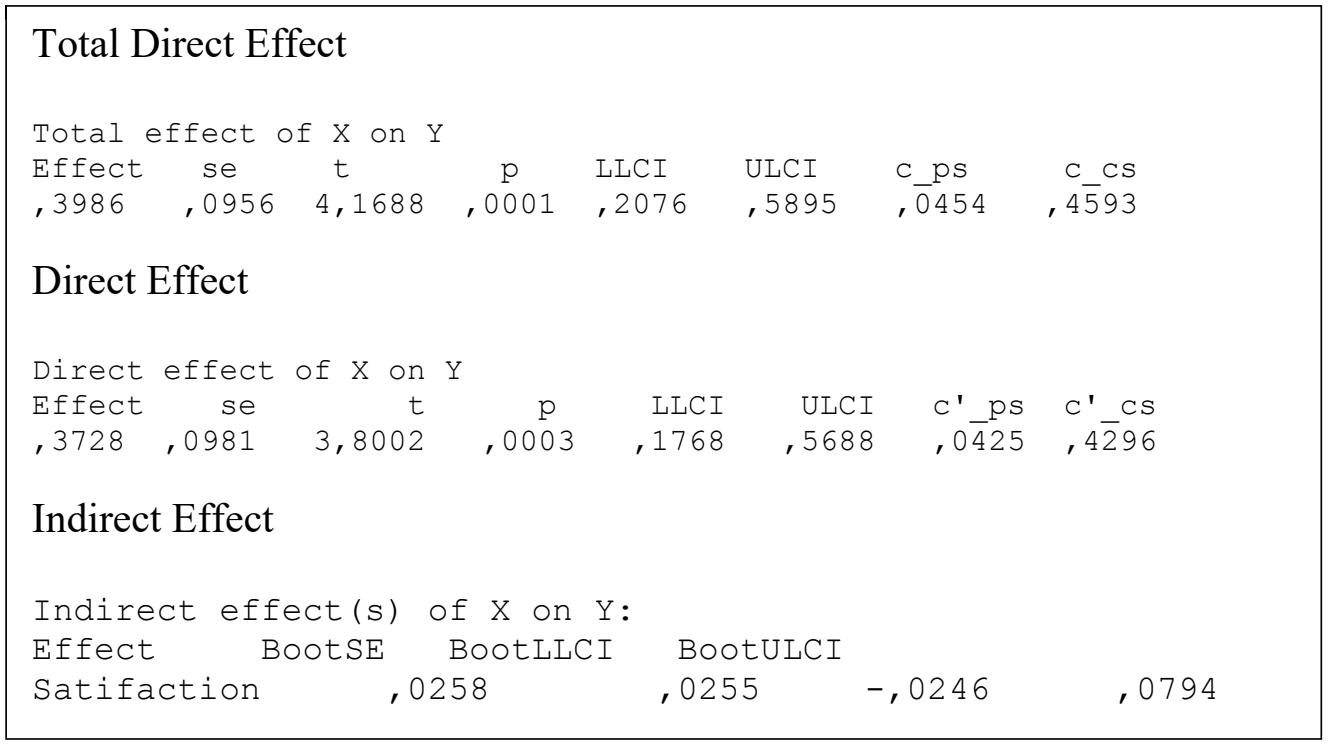

Fig 2. Sobel Test Result

The role of mediation can also be seen from the $t_{\text {count }}$ value based on the output above of 4.1688. The value of $t_{\text {count }}$ was compared with the value of $t_{\text {table, }}$, which indicated the value of $>1.96$. Since the $t$ value was higher than $t$ table, it can be be concluded that there was a mediation effect. It was shown that the value was 4.1688 or $>1.96$, which indicated that there was a mediating role between the $\mathrm{X}$ to $\mathrm{Y}$ variables through the $\mathrm{Z}$ variable.

\section{Effect of job promotion on employee performance $=\mathbf{0 . 3 7 3}$}

The value of the path coefficient of promotion on employee performance directly was 0.373 and the results of the $\mathrm{T}_{\text {test }}$ statistical test (partial test) showed a significant value of promotion on employee performance of 0.000 since the path coefficient value was $(0.373)$ and the significance value was lower than $0.05(0.000<0.05)$. This meant that there was a direct effect of job promotion on employee performance, which indicated that the better the implementation of employee promotion, the higher the ASN performance in the Regional Office of the Ministry of Religion of Banten Province. The results of this study are in accordance with the study conducted by Wahyu Maulana [9] entitled "Effect of Job Promotion, Compensation, and Job Stress on Employee Performance of PT. Tema 
(Trijaya Exel Madura) through Job Satisfaction as an Intervening Variable" which found that there was a significant effect of promotion on employee performance.

\section{Effect of Job Promotion on Job Satisfaction $=0.207$}

The value of the path coefficient of job promotion on job satisfaction directly was 0.207 and the results of the $\mathrm{T}_{\text {test }}$ statistical test (partial test) showed a significance value of job promotion on employee performance of 0.058 , the path coefficient value of $(0.207)$ and the significance value was higher than $0.05(0.058>0.05)$. This meant that there was no direct and significant effect of promotion on employee performance. The results of this study are in accordance with the study conducted by Made Surata and Wayan Arya Paramarta [14] entitled "Effect of Mutation and Position Promotion Policies on Employee Performance in the Public Administration and Finance Section at Bali State Polytechnic through Job Satisfaction as an Intervening variable, which found that there was no significant effect of promotion on job satisfaction.

\section{Effect of Job Satisfaction on Employee Performance $=0.124$}

The value of the path coefficient of job satisfaction on employee performance directly was 0.124 and the results of the $\mathrm{T}_{\text {test }}$ statistical test (partial test) showed a significance value of job satisfaction of 0.264 , the path coefficient value of $(0.124)$ and the significance value that was higher than $0.05(0.264>0.05)$. This meant that there was no direct effect of job satisfaction on employee performance.

The results of this study are in accordance with the study conducted by Ayu Puspitasari and Wawan Prahiawan [11] entitled "Effect of Preventive Discipline and Extrinsic Motivation on Employee Performance through Job Satisfaction as an Intervening Variable at PT. Natura Indoland" which found that there was no positive and significant effect of job satisfaction on employee performance.

Effect of Job Promotion on Employee Performance through Job Satisfaction $=\mathrm{X1Z} \times \mathrm{ZY}=$ $0.207 \times 0.124=0.025$

The value of the indirect effect was obtained from the value of the path coefficient of job promotion on job satisfaction multiplied by the value of the path coefficient of job satisfaction on employee performance of $(0.207 \times 0.124)=0.025$. The results of the $T_{\text {test }}$ statistical test (partial test) showed the significant value of position promotion on job satisfaction of 0.058 and the significance value of job satisfaction on employee performance was 0.264 . The significance value was higher than 0.05 , which meant that the indirect effect of promotion on employee performance through job satisfaction had no direct and significant effect. The multiplication result showed that the value of the indirect effect coefficient (XZ x ZY) was lower than the value of the direct effect coefficient of XY $(0.025<0.373)$. The results of this study are in accordance with the study conducted by Wahyu Maulana [8] entitled "Effect of Leadership, Compensation, and Job Promotion on Employee Performance through Job Satisfaction as an Intervening Variable at PT. bank Jatim, Tbk Pamekasan Branch" which found that job satisfaction was not an intervening variable on the effect of promotion on employee performance.

\section{CONCLUSIONS}

Based on the results of the analysis and discussion, it can be concluded that promotion had a direct effect on employee performance. This indicated that the better the implementation of promotion, the better the employee performance would be. Ther was no direct effect of job promotion on employee job satisfaction. This is due to job promotions were done in a non-transparent manner and caused other employees to be dissatisfied with the promotion. Job satisfaction had no direct effect on employee performance. Employee dissatisfaction might occur and had an impact on employee performance. It was indicated by the low attendance level of many employees who were frequently absent. Furthermore, the indirect effect of Job Promotion on Employee Performance through Job Satisfaction 
showed a smaller percentage compared with the percentage of direct effect. Thus, it was indicated that without job satisfaction, employees would continue to improve their performance so that they could be promoted by the boss.

\section{ACKNOWLEDGEMENT}

The author would like to express gratitude to Bina Bangsa University for the support and encouragement during the process until the completion of this study.

\section{REFERENCES}

[1] Edison, Emron, Yohny Anwar \& Imas Komariyah, (2016). Human Resource Management. Bandung: Alfabeta,

[2] Fahmi, Irham. (2016). Human Resource Management, theory and application, Bandung: Alfabeta.

[3] Gomes, Faustino Cardoso. (2003). Human Resource Management. Jakarta: Andi Offset

[4] Hasibuan, Malayu, S.P. (2003). Organization and Basic Motivation for Increasing Productivity. Jakarta: Earth Literacy

[5] Hasibuan, Malayu, S.P. (2016). Human Resource Management. Jakarta: Earth Literacy.

[6] Levi. (2002). Accessed on 9th December 2020 from https://www.seputarpeng knowledge.co.id/2017/08/17pengentuk-kepuas-kerja-menurut-para-ahli-teori-aspek-faktor.html.

[7] Mangkunegara, Anwar Prabu. (2015). HR Evaluation. Bandung: PT. Refika Aditama.

[8] Maulana. Wahyu. (2018). Effect of Leadership, Compensation, and Job Promotion on Employee Performance at PT. Bank Jatim, Tbk Pamekasan Branch Mediated by Job Satisfaction, Macro, Journal of Management \& Entrepreneurship. Vol. 3 No. 1.

[9] Maulana. Wahyu. (2019). Effectof Job Promotion, Compensation, and Work Stress on Employee Performance at PT. Theme (Trijaya Exel Madura) Mediated by Job Satisfaction. BMJ Business Management Analysis Journal. Vol. 2 No. 1.

[10] Moeheriono. (2014), Competency-Based Performance Measurement, Revised Edition, Jakarta: PT RajaGrafindo Persada

[11] Puspitasari. Ayu. et al. (2018). Effect of Preventive Discipline and Extrinsic Motivation on Employee Performance at PT. Natura Indoland Mediated by Job Satisfaction, Tirtayasa Ekonomika. Vol. 13 No. 2.

[12] Robbins. (2015). Organizational Behavior, 16th Edition. Jakarta: Salemba Empat.

[13] Saefullah, Encep. et al. (2019). Effect of Leadership Style on the Performance of Honorary Teachers at SMK Insan Mulya Kibin Mediated by Discipline. Journal of Bina Bangsa Ekonomika (JBBE). Vol. 12 No. 1.

[14] Surata. Made. et al. (2015). The Effect of Mutation and Position Promotion Policies on Employee Work Performance in the Public Administration and Finance Section at Bali State Polytechnic Mediated by Job Satisfaction. Soshum: Journal of Social and Humanities. Vol. 5 No. 2.

[15] Sutrisno, Edy. (2014). Human Resource Management, Jakarta: Prenade media Group. 